\title{
VILLAGE TOURISM DEVELOPMENT WITH SHARING GRANTS MODEL THE SOLUTION TO PROMOTE VILLAGE SOVEREIGNTY
}

\author{
By: \\ Wahju Gunawan (wahyugunawanbandung@gmail.com) \\ Desi Yunita (dey.radsya@gmail.com) \\ Lecturer of Sociology Study Program, Faculty of Social Studies \\ Padjajaran University
}

One of development strategyin an effort to encourage rural economic growth is to make it as a tourist village, especially for villages which have valuable in tourism potential. In accelerate the development of a village into a tourism village it desperately needed the cooperation and support of many parties, because it pertains to the resources needed in that development. One of the concepts developed are sharing grants.That is a concept to encourage as many parties that have to be involved to develop the idea of understanding the village with herding resources owned by the parties.So that all the stakeholders involved will jointly engage independently. The purpose of development of rural tourism with the concept of sharing grants is to encourage the community to be involved in accordance with their desire and ability, so that the existence of these stakeholders will be an umbrella which can be placed the society. To make the changes beneficial in the implementation, it is necessary to make a guideline that would be the corridor of the village tourism development.

Keywords: Economic Growth, Tourism Villages, Sharing Grants

\section{Pendahuluan}

Impian untuk menjadikan desa sebagai ujung tombak pembangunan sudah sejak lama digaungkan. Hal ini bukanlah sesuatu yang mustahil, melihat banyaknya jumlah desa dan besarnya potensi yang dimiliki oleh desa yang ada di Indonesia. Badan pusat statistik mencatat bahwa terdapat 80.000 desa/kelurahan dimana 32.000 diantaranya 
termasuk dalam kategori desa miskin ${ }^{1}$. Fakta inilah yang mendorong pemerintah melakukan upaya pembangunan, pembinaan, dan pemberdayaan masyarakat desa.

Dalam Undang-undang Nomor 6 Tahun 2014 tentang desa pada pasal empat, pemerintah secara tegas menyebutkan bahwa upaya pembangunan, pembinaan dan pemberdayaan yang dilakukan tersebut bertujuan untuk melestarikan dan memajukan adat, tradisi, dan budaya masyarakat Desa; mendorong prakarsa, gerakan, dan partisipasi masyarakat desa untuk pengembangan potensi dan aset desa guna kesejahteraan bersama; meningkatkan ketahanan sosial budaya masyarakat desa guna mewujudkan masyarakat desa yang mampu memelihara kesatuan sosial sebagai bagian dari ketahanan nasional; memajukan perekonomian masyarakat desa serta mengatasi kesenjangan pembangunan nasional; dan memperkuat masyarakat desa sebagai subjek pembangunan.

Hal tersebut menunjukkan bahwa pembangunan desa selayaknya tetap mengedepankan identitas desa di

satu sisi, namun juga dapat meningkatkan pertumbuhan ekonomi masyarakat desa di sisi yang lain. Oleh karenanya desa-desa yang telah memiliki pengetahuan yang baik mengenai potensinya saat ini terus bergeliat untuk membangun dan mengembangkan diri, melalui inovasiinovasi yang berangkat dari potensi-potensi yang dimilikinya tersebut.

Salah satu inovasi pengembangan ekonomi desa yang saat ini mencuat adalah pengembangan desa wisata. Upaya mengembangkan desa sebagai destinasi wisata tersebut sangat sejalan dengan visi pembangunan kepariwisataan nasional Indonesia yang menuntut upaya terwujudnya Indonesia sebagai negara tujuan pariwisata berkelas dunia, berdaya saing, berkelanjutan, dan mampu mendorong pembangunan daerah dan kesejahteraan rakyat ${ }^{2}$.

Kabupaten Bandung Barat, sebagai salah satu daerah yang telah sejak lama dikenal sebagai daerah tujuan wisata baik lokal maupun internasional karena beberapa site pariwisata yang dimilikinya di Jawa Barat, juga terus mengembangkan diri pada sektor pariwisata. Salah satu alternatif pengembangan tersebut adalah dengan mendorong pengembangan desa wisata. Terutama bagi desa-desa yang memiliki potensi pariwisata serta infrastruktur pendukung yang baik.

1http://www.republika.co.id/berita/nasional/umum/13/01/31/mhgb3i-ada-32-ribudesa-di-indonesia-kategori-tertinggal

2 UU No. 10 Tahun 2009 Tentang Kepariwisataan 
Salah satu desa yang saat ini juga sedang mengembangkan diri menjadi Desa Wisata di Kabupaten Bandung Barat adalah desa Jayagiri Kecamatan Lembang. Adapun upaya pengembangan desa wisata ini dapat dilihat sebagai salah satu strategi pembangunan pedesaan yang akan menjadi suatu kesempatan yang baik untuk mendorong kemajuan desa.

Beberapa faktor yang melandasi pemilihan strategi pembangunan dengan menjadikan desa Jayagiri sebagai desa wisata ini tidak terlepas dari pesatnya pertumbuhan pariwisata di Indonesia saat ini. Pusdatin Kementerian Pariwisata dan Ekonomi Kreatif dan BPS pada tahun 2009 mencatat bahwa terdapat 6.323 .730 wisatawan mancanegara yang berkunjung ke Indonesia dan terus meningkat menjadi 8.802.129 pada tahun 2013. Sementara untuk wisatawan nusantara, jumlah perjalanan wisata mencapai 229.731,000 pada tahun 2009 dan terus meningkat menjadi 248.000,000 di tahun 2013. Sedangkan dari sisi penerimaan devisa juga terus mengalami peningkatan dari US\$ 6.297.99 juta pada tahun 2009 menjadi US\$ 10.054.140 pada tahun 2013. Hal ini kemudian menempatkan sektor pariwisata di peringkat ke-5 setelah komoditas minyak dan gas bumi, batu bara, kelapa sawit dan karet olahan ${ }^{3}$.

Fakta lain yang juga menjadi landasan pemilihan menjadi desa wisata ini juga dilihat dari data bahwa, pertumbuhan desa wisata di Indonesia juga mengalami perkembangan yang sangat pesat. Berdasarkan data yang dikeluarkan oleh kementerian pariwisata dan ekonomi kreatif (Kemenparekraf) diketahui bahwa telah terjadi pertumbuhan desa wisata yang sangat signifikan yaitu dari 144 desa wisata pada tahun 2009 menjadi 978 desa wisata pada saat ini ${ }^{4}$. Angka tersebut menunjukkan bahwa desa wisata telah menjadi alternatif pariwisata yang cukup diminati oleh wisatawan. Oleh karenanya kesempatan tersebut perlu disambut dengan baik.

Dari dua data mengenai pertumbuhan wisatawan dan juga mengenai pertumbuhan desa wisata tersebut, maka dapat dilihat bahwa pariwisata telah terbukti dapat mendorong pertumbuhan perekonomian melalui peluang investasi, peluang kerja, peluang berusaha dan pada akhirnya dapat meningkatkan kesejahteraan masyarakat. Akan tetapi, sektor pariwisata massal (mass tourism) yang telah berkembang selama ini bukannya tidak memberikan dampak bagi masyarakat di sekitar lokasi

3http:/ / www.parekraf.go.id/asp/detil.asp?c=110\&id=1408

${ }^{4}$ http://etd.repository.ugm.ac.id/downloadfile/72431/potongan/S1-2014-302193chapter1.pdf 
wisata tersebut. Pariwisata massal tersebut disisi lain juga telah menyebabkan malapetaka terhadap kehidupan sosial, budaya dan lingkungan.

Kesejahteraan ekonomi yang diperoleh dari pariwisata tersebut ternyata tidak diikuti dengan peningkatan kehidupan sosial, budaya dan pelestarian lingkungan. Oleh karenanya diperlukan suatu strategi dan pendekatan khusus dalam pengembangan pariwisata desa tersebut, agar pengembangan pariwisata tersebut memberikan dampak positif baik secara sosial, ekonomi maupun lingkungan.

Latar belakang tersebutlah yang melandasi pemikiran untuk mengembangkan konsep pariwisata yang ramah lingkungan, dan berkelanjutan, atau lebih dikenal dengan ekowisata (ecotourism). The International Ecotourism Society mendefinisikan ekowisata sebagai "perjalanan bertanggung jawab kedaerah alam yang melestarikan lingkungan, menopang kesejahteraan masyarakat setempat, dan melibatkan interpretasi dan edukasi" (TIES, 2015)5. Dengan kata lain ekowisata dapat juga dikatakan sebagai upaya penyatuan konservasi, masyarakat dan perjalanan yang berkelanjutan. Sehingga mempersiapkan masyarakat menjadi salah satu faktor kunci bagi pengembangan tersebut.

\section{Desa sebagai Objek Ekowisata}

Banyak desa di Indonesia memiliki potensi untuk dikembangkan menjadi lokasi ekowisata. Hal ini dilihat dari nilai-nilai budaya yang masih ada dan berkembang dalam masyarakat, karakteristik dan keunikannya, serta daya tarik lain yang dimiliki oleh suatu desa.

Salah satu desa yang memiliki potensi unik untuk dikembangkan sebagai objek ekowisata tersebut adalah desa Jayagiri, kecamatan lembang kabupaten bandung barat. Desa ini adalah desa yang letaknya berada diperlintasan menuju objek wisata Gunung Tangkuban Parahu. Keunikan desa tersebut adalah, dari desa ini wisatawan dapat menikmati pemandangan hutan alam yang masih asri untuk menuju ke Gunung Tangkuban Parahu. Selain dari potensi tersebut ada beberapa potensi lain yang juga cukup unik untuk dikembangkan sebagai daya tarik ekowisata. Akan tetapi dalam pengembangan ekowisata tersebut, tentulah harus memperhatikan kaidah-kaidah yang menjadi prinsip dalam ekowisata. Kaidah-kaidah tersebut penting untuk menjaga dan melindungi potensi wisata yang ada tersebut agar memiliki manfaat ekonomi yang

5https:/ / www.ecotourism.org/what-is-ecotourism 
berkelanjutan. Gaymans (dalam Malek-Zadeh. 1996: 160-168) menyebutkan ada lima parameter dalam pengembangan ekowisata yaitu: pertama, mengurangi dampak pada lingkungan atau keberlanjutan lingkungan. Kedua, interaksi dengan alam. Ketiga, keterlibatan komunitas dan interaksi dengan orang. Keempat, aktivitas lingkungan, dan kelima keberlanjutan ekonomi.

Sehingga pengembangan wisata desa yang dilakukan di desa Jayagiri, jika mengacu pada parameter yang dikemukakan oleh Gaymans (1996:161) tersebut haruslah secara ketat dan selektif melaksanakan prinsip-prinsip ekowisata tersebut. oleh karena itu, dengan adanya keterbatasan-keterbatasan yang dimiliki oleh masyarakat desa untuk mengembangkan program ekowisata tersebut. Maka diperlukanlah pihak luar yang memiliki kepedulian dan concern yang sama dalam mengembangkan ekowisata tersebut untuk terlibat. Kebutuhan akan pihak luar tersebut setidaknya diarahkan untuk menyusun dan merencakan model ekowisata yang akan dipilih tanpa meninggalkan atau menegasikan peran penting dari masyarakat lokal tentunya.

Sejalan dengan hal tersebut, Sproule (dalam Malek-Zadeh 1996:242) menyebutkan bahwa ketika mengembangkan ekowisata, sangat penting untuk bekerjasama dengan organisasi lain. Beberapa mitra penting dalam mengembangkan bisnis ekowisata berbasis masyarakat diantaranya dengan industri pariwisata yang telah ada terutama dengan operator tur, biro pariwisata pemerintah dan pengelolaan sumberdaya alam seperti hutan lindung, organisasi non pemerintah (LSM) terutama yang terlibat dengan isu-isu lingkungan, pengelolaan usaha kecil, dan pengembangan masyarakat tradisional, universitas dan organisasi penelitian lainnya, dan kelompok-kelompok yang memiliki peran dalam mengembangkan ekowisata.

\section{Pengembangan Pariwisata Model Sharing Grants}

Berdasarkan uraian yang telah diuraikan sebelumnya, dapat dilihat bahwa selain perlunya inisiatif dari dalam masyarakat, penting juga kiranya mendorong inisiatif-inisiatif ekternal untuk terlibat dalam membantu pengembangan ekowisata desa tersebut.

Sebagai desa yang berdekatan dengan objek wisata Gunung Tangkuban Parahu di kabupaten bandung barat. Desa Jayagiri sangat strategis dikembangkan sebagai desa wisata. Beberapa potensi pariwisata yang dimiliki oleh desa ini diantaranya rute/track menuju gunung 
Tangkuban Parahu dengan berjalan kaki, melintasi perladangan masyarakat dan pemandangan hutan, yang akan menjadi potensi pariwisata pertualangan yang menarik. Di desa ini juga terdapat benteng peninggalan belanda yang saat ini hampir sebagian besar bangunannya telah tertutup tanah, serta beberapa peninggalan bersejarah lainnya juga dapat dijumpai di desa ini, tentunya akan menjadi suatu potensi pariwisata yang menarik. Lokasinya yang berdekatan dengan gunung tangkuban parahu ini juga telah mendorong sebagian kecil masyarakat mengembangkan usaha-usaha kreatif untuk menunjang pariwisata gunung tangkuban parahu. Beberapa potensi tersebutlah yang mendorong munculnya gagasan pengembangan desa wisata ini.

Meskipun memiliki potensi pariwisata yang cukup banyak, namun semua potensi yang ada tersebut masih perlu dilakukan pembenahan dan pengembangan-pengembangan sehingga menjadi lokasi wisata yang menarik untuk dikunjungi oleh wisatawan. Sehingga, layaknya sebuah objek wisata yang menawarkan keunikan. Maka dalam pengembangan ekowisata desa ini juga setidaknya ada tiga hal yang menjadi fokus pengembangan tersebut yaitu; atraksi, akomodasi, dan fasilitas pendukung pariwisata (Nuryanti,1993) ${ }^{6}$.

Upaya pengembangan pariwisata tersebut tentunya membutuhkan sumberdaya yang tidak sedikit, baik sumberdaya finansial, ide, SDM, atau sumberdaya lain yang akan bermanfaat bagi pengembangan desa wisata, oleh karenanya selain dari partisipasi aktif masyarakat dalam pengembangan tersebut, juga diperlukan pihak ketiga atau outsiders yang akan melihat dan menilai dengan lebih objektif dan informasi yang lebih beragam.

Kebutuhan akan adanya pihak ketiga dalam pengembangan desa wisata yang tidak akan bertindak sebagai investor dalam pengembangan desa wisata inilah yang memunculkan ide pelibatan stakeholders dalam pengembangan ekowisata desa dengan menggagas model pengembangan pariwisata secara sharing grants.

Gagasan pengembangan model sharing grants ini adalah suatu cara untuk mempertemukan beberapa kelompok stakeholder yang memiliki kesamaan ide dalam pengembangan pariwisata desa. Agar

${ }^{6}$ Desa wisata adalah suatu bentuk integrasi antara atraksi, akomodasi dan fasilitas pendukung yang disajikan dalam suatu struktur kehidupan masyarakat yang menyatu dengan tata cara dan tradisi yang berlaku (Nuryanti, Wiendu. 1993. Concept, Perspective and Challenges, makalah bagian dari Laporan Konferensi Internasional mengenai Pariwisata Budaya.Yogyakarta: Gadjah Mada University Press. Hal. 2-3) dikutip dari http://id.wikipedia.org/wiki/Desa_wisata 
pengembangan pariwisata tersebut efektif dan tepat sasaran maka digagaslah suatu pertemuan dengan semua stakeholder untuk mengetahui ide-ide pengembangan desa wisata yang akan dikembangkan oleh masing-masing stakeholders tersebut. Sehingga tidak terjadi tumpang tindih dalam pengembangan wisata. Selain itu, gagasan pengembangan pariwisata dengan model sharing grants ini juga untuk mendorong partisipasi para pihak yang memiliki kepedulian (concern) yang sama terkait pengembangan ekowisata desa.

Sharing grants yang dimaksudkan disini adalah suatu gagasan untuk mempertemukan kepentingan pengembangan ekowisata desa oleh stakeholders yang terlibat dalam pengembangan ekowisata desa untuk mengembangkan suatu desa menjadi lokasi ekowisata dengan mencari sumber pendanaan secara mandiri untuk mengembangkan ekowisata desa di Desa Jayagiri tersebut. Sehingga antara satu stakeholders dengan stakeholders lainnya akan mencari dukungan sesuai dengan rencana pengembangan desa yang akan dilakukan yang disesuaikan dengan rencana pengembangan desa wisata secara keseluruhan. Setiap stakeholder diberi keleluasaan untuk menggali pendanaan secara mandiri untuk mendukung pengembangan desa wisata tersebut, tanpa harus terikat antara satu sama lainnya. Dari pengembangan desa wisata dengan menggunakan konsep ini diharapkan dapat semakin memperkaya model pariwisata desa yang akan dikembangkan, dengan tetap menjadikan masyarakat desa sebagai pelaku utamanya.

Untuk lebih jelasnya bagaimana skema sharing grants tersebut bekerja dalam pengembangan wisata desa Jayagiri dapat dilihat pada bagan dibawah ini: 


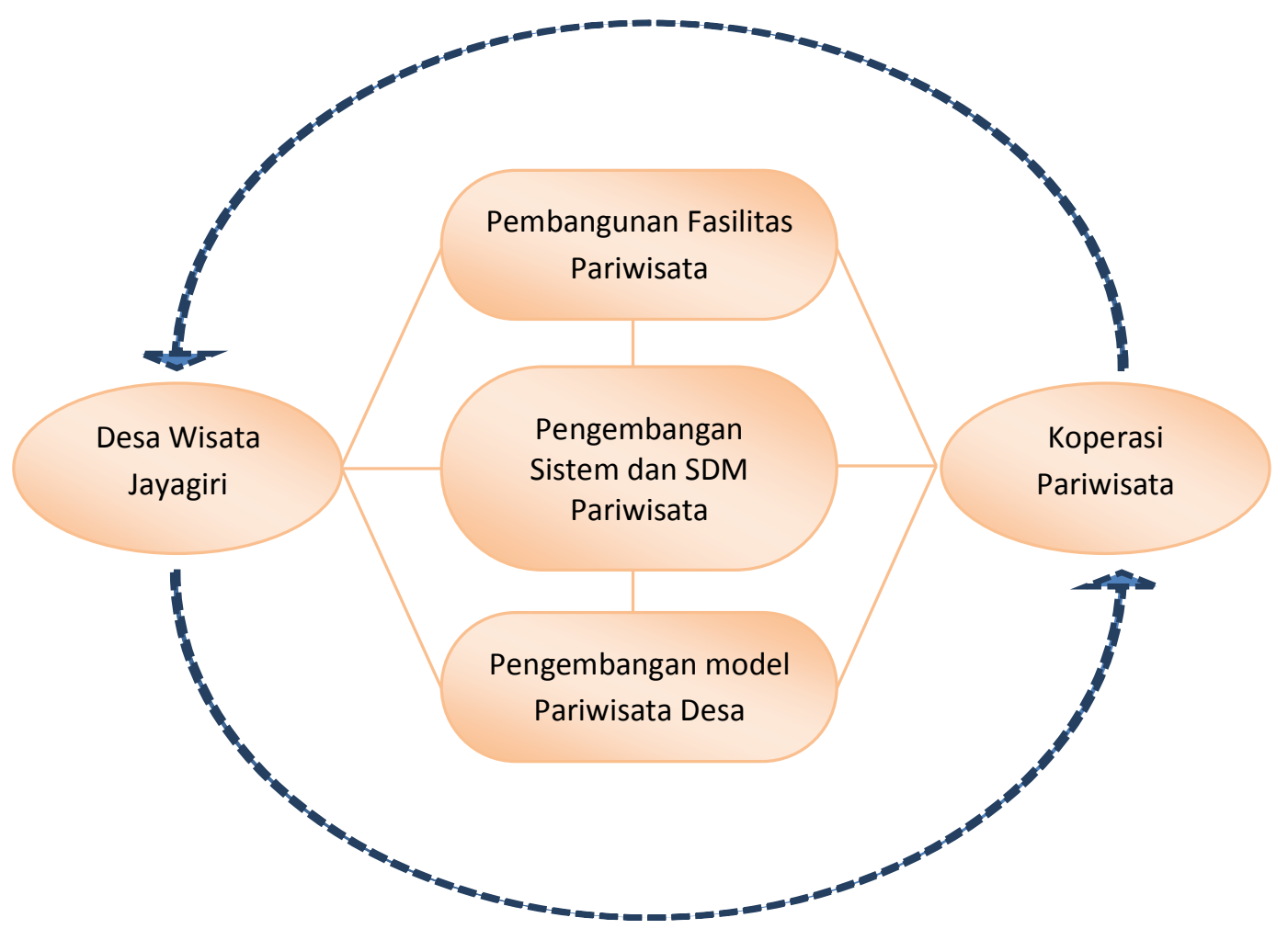

Dari bagan tersebut dapat dilihat bahwa pengembangan desa wisata ini, meskipun melibatkan pihak-pihak dari luar masyarakat desa juga tetap mengedepankan prinsip-prinsip pengembangan ekowisata berbasis pedesaan. Beberapa aspek kunci dalam pengembangan desa wisata berbasis masyarakat tersebut adalah: masyarakat membentuk panitia atau lembaga utuk pengelolaan kegiatan ekowisata di desa dengan dukungan dari pihak luar baik pemerintah maupun organisasi masyarakat; prinsip local ownership (pengelolaan dan kepemilikan oleh masyarakat setempat) diterapkan sedapat mungkin terhadap saran dan pra sarana ekowisata, kawasan wisata, dll; Homestay menjadi pilihan utama utuk sarana akomodasi di lokasi wisata; pemandu adalah orang setempat; dan perintisan, pengelolaan dan pemeliharaan objek wisata menjadi tanggung jawab masyarakat setempat, termasuk penentuan biaya untuk wisatawan. Dari beberapa prinsip tersebut dapat dilihat bahwa prinsip desa wisata yang dikemukakan tersebut sangat mengedepankan nilai-nilai partisipasi masyarakat, nilai ekonomi dan juga nilai edukasi.

Jika dilihat pada bagan tersebut, setidaknya ada tiga aktivitas yang membutuhkan pendanaan dan hal tersebut diserahkan sepenuhnya 
kepada stakeholder untuk mengatasinya yaitu, pengembangan fasilitas wisata, pengembangan sistem, dan pengembangan model. Meskipun terlihat seperti terpisah, namun kegiatan-kegiatan tersebut menjadi suatu kesatuan yang utuh sehingga penting kiranya bagi stakeholder yang terlibat di masing-masing aktivitas tersebut untuk mencari pendanaan. Proses pengembangan melalui proses pendanaan secara mandiri inilah yang dimaknai sebagai sharing grants.

Agar pengembangan desa wisata ini terukur dan terarah, serta dapat memberikan kontribusi langsung bagi masyarakat, dibentuklah koperasi sebagai wadah pengembangan ekonomi dari wisata desa tersebut. Dengan dibentuknya koperasi ini, stakeholders dan masyarakat desa, menjadi anggota koperasi dan mendapatkan manfaat ekonomi dari adanya pariwisata desa tersebut. Hal ini secara positif menjadikan masyarakat secara merata menjadi penerima manfaat dari pengembangan ekowisata desa tersebut. Di sisi lain, stakeholders yang secara mandiri telah terlibat dalam mengembangkan ekowisata desa tersebut juga mendapatkan keuntungan jangka panjang dengan terlibat secara langsung dalam koperasi tersebut.

Pembentukan koperasi ini juga penting dilakukan sebagai bentuk pengawasan perkembangan pariwisata desa yang telah berjalan, sehingga bisnis pariwisata desa tersebut benar-benar akan memberikan kontribusi bagi perkembangan kemajuan desa dan meningkatkan kesejahteraan ekonomi masyarakat desa dan anggota dari koperasi tersebut. Hal ini sejalan dengan prinsip koperasi seperti yang tertuang dalam UU No. 17 Tahun 2012, terutama pada poin ketujuh; yaitu koperasi bekerja untuk pembangunan berkelanjutan bagi lingkungan dan masyarakat melalui kebijakan yang disepakati oleh anggota.

Pengembangan desa wisata yang diselaraskan dengan pembentukan koperasi sebagai unit usaha yang menggerakkan pariwisata tersebut secara positif akan memberikan dampak pada bidang ekonomi maupun pada kehidupan sosial masyarakat. Karena keberadaan koperasi tersebut akan meningkatkan penghasilan anggota-anggota koperasi tersebut secara ekonomi. Serta mendorong terwujudnya kehidupan yang damai dalam masyarakat dan mendidik anggota dan masyarakat desa umumnya untuk memiliki semangat kerjasama dan semangat kekeluargaan.

Partisipasi kelompok eksternal (stakeholders) dalam pengembangan wisata desa menunjukkan bahwa modal sosial masih bertumbuh dengan baik. Berkembangnya modal sosial tersebut akan 
menghasilkan kesejahteraan dan oleh karenanya bagian dari nilai ekonomi bagi ekonomi nasional. Sehingga pembangunan desa wisata ini juga menjadi model upaya kelompok dalam membuat suatu tata aturan dalam masyarakat yang ditujukan untuk meningkatkan kesejahteraan masyarakat itu sendiri. Meskipun ada keterlibatan pihak-pihak dari luar masyarakat desa itu sendiri. Namun hal itu justru memungkinkan semakin berkembangnya komunikasi dalam masyarakat dan mengkoordinasikan tindakan-tindakan sosial.

Pengembangan desa wisata dengan model sharing grants ini juga secara sederhana dapat didefinisikan sebagai pembentukan nilai-nilai atau norma-norma informal bersama diantara stakeholder dan para anggota kelompok masyarakat yang memungkinkan terjalinnya kerjasam di antara mereka.

\section{Kesimpulan}

Semangat menjaga dan melestarikan nilai-nilai, budaya tradisional dan juga lingkungan dengan mengembangkan desa wisata adalah wujud nyata dari berdaulatnya desa. Dengan kreativitas dan inovasi pengembangan desa wisata, baik pada proses penggalian potensi, perencanaan, dan pelaksanaan pengembangan desa wisata telah menunjukkan bahwa desa Jayagiri telah memiliki kemandirian untuk mengembangkan desa wisata meskipun dalam proses pengembangannya tetap melibatkan pihak-pihak dari luar desa. Namun keterlibatan tersebut tidaklah mengikis rasa kepemilikan desa wisata oleh masyarakat. Peran dan partisipasi para pihak diluar masyarakat desa tersebut lebih sebagai penguat dan pendamping agar pengembangan desa tersebut sesuai dengan rencana pengembangannya.

Semakin berkembangnya desa wisata yang ditandai dengan semakin besarnya partisipasi masyarakat dalam rencana pengembangan menunjukkan bahwa terjadi penguatan pada modal sosial dalam masyarakat. Hal tersebut dibuktikan dengan dibentuknya koperasi desa wisata, dengan komitmen yang kuat dari para pihak untuk terlibat dan menjadi bagian dari upaya pengembangan desa wisata tersebut.

Semakin besarnya partisipasi masyarakat itu juga menunjukkan terjadinya penguatan pada modal sosial dalam masyarakat seperti, kejujuran, saling mempercayai, pemenuhan tugas, kesediaan untuk saling menolong dan komitmen bersama.Tanpa modal sosial yang baik 
pengembangan desa wisata Jayagiri tersebut tidak akan mudah diwujudkan.

Daftar Pustaka

Fukuyama, Francis. 2002. The Great Disruption. Hakikat Manusia dan Rekonstruksi Tatanan Sosial

Yoeti, Oka A. 2008. Ekonomi Pariwisata. Introduksi, Informasi, dan Aplikasi. Kompas Gramedia. Jakarta

Dr Richard Denman, The Tourism Company.2001. Guidlines for communitybased ecotourism development. WWF International.

WWF Indonesia. 2009. Prinsip dan Kriteria Ekowisata Berbasis Masyarakat. Kemenbudpar-WWF-Indonesia. Jakarta

Dirjen Bina Pembangunan Daerah Kemendagri. 2013. Petunjuk Pelaksanaan Pengelolaan dan Pengembangan Kawasan Ekowisata Berbasis Masyarakat. Kemendagri. Jakarta.

http://www.republika.co.id/berita/nasional/umum/13/01/31/mhgb3iada-32-ribu-desa-di-indonesia-kategori-tertinggal

UU No. 10 Tahun 2009 Tentang Kepariwisataan

http:/ / www.parekraf.go.id/asp/detil.asp?c=110\&id=1408

http:/ / etd.repository.ugm.ac.id/downloadfile/72431/potongan/S1-2014302193-chapter1.pdf

Nuryanti, Wiendu. 1993. Concept, Perspective and Challenges, makalah bagian dari Laporan Konferensi Internasional mengenai Pariwisata Budaya.Yogyakarta: Gadjah Mada University Press. Hal. 2-3) dikutip dari http://id.wikipedia.org/wiki/Desa_wisata

Malek-Zadeh, Elisabeth, ed. 1996. Bulletin 099. The Ecotourism Equation: Measuring the Impacts. Yale School of Forestry \& Environmental Studies.USA 